\title{
STRATEGI PENINGKATAN DAYA SAING INDUSTRI BANDENG DI KABUPATEN INDRAMAYU
}

\author{
(INCREASING COMPETITIVENESS STRATEGY OF MILKFISH INDUSTRY IN INDRAMAYU)
}

\author{
Ia Arga Dhelia*, Rina Oktaviani**, Budhi Hascaryo Iskandar*** \\ *) Sekolah Bisnis - Institut Pertanian Bogor \\ Jl. Raya Pajajaran, Bogor 1615 \\ **) Program Pascasarjana Magister Sains Agribisnis, Institut Pertanian Bogor \\ Jl. Kamper, Wing 4 Level 3, Kampus IPB Dramaga, Bogor 16680 \\ ***) Departemen Agribisnis, Fakultas Ekonomi dan Manajemen, Institut Pertanian Bogor \\ Jl. Kamper Wing 2 Level 5, Kampus IPB Darmaga Bogor 16680
}

Naskah diterima: 29 Juli 2017

Naskah direvisi: 30 April 2018

Naskah diterbitkan: 30 Juni 2018

\begin{abstract}
The fisheries sector played an important role in the formation of national gdp with the capture fisheries and aquaculture sector as the main pillar. Director general of aquaculture claimed that milkfish is an option to increase aquaculture production that has not yet been optimized though it is affordable, rich in the womb nutrition, easy to cultivate, and will raise the income of the coastal communities. West Java were the third largest of milkfish producers in Indonesia and more than half of its production produced in Indramayu. Indramayu had the largest pond potential in West Java. Its production always beyond the target and increased each years. The purpose of this study is to identify the factual condition of milkfish fisheries in Indramayu, analyze industrial competitiveness of milkfish in Indramayu, and find the policy strategy to improve industrial competitiveness of milkfish in Indramayu. The analytical methods used were Porter's diamond model, gap analysis, and anaytical hierarchy process (AHP). The results of the analysis showed that Indramayu can increase its competitiveness by concern to the several factors, such as increasing the quality of human resources, the creation of accessibility capital resources, strengthening infrastructure, and ease cooperation with supporting industry and related industries. The main factor was capital resources, with main actor and objective were businessman and to increase income of it. The following alternative strategies based on priority were increase production strategy, infrastructure strengthening strategy, cooperation strengthening among stakeholders, counseling strategy, and regulatory improvement strategy.

Keywords: AHP, competitiveness, gap analysis, milkfish industry, Porter's diamond model
\end{abstract}

\begin{abstract}
Abstrak
Sektor perikanan berperan penting dalam pembentukan PDB nasional dengan tumpuan utama sektor perikanan tangkap dan budidaya perikanan. Dirjen Perikanan Budidaya menyatakan ikan bandeng merupakan salah satu pilihan untuk meningkatkan produksi perikanan budidaya yang belum optimal meskipun harganya terjangkau, kaya akan kandungan gizi, budidaya mudah dilakukan, dan dapat meningkatkan pendapatan masyarakat pesisir. Provinsi Jawa Barat menjadi produsen bandeng terbesar ke tiga di Indonesia dan lebih dari setengah produksinya dihasilkan di Kabupaten Indramayu. Kabupaten Indramayu memiliki potensi tambak terluas di Jawa Barat. Produksinya selalu melampaui target dan meningkat setiap tahunnya. Tujuan dari penelitian ini adalah mengidentifikasi kondisi faktual perikanan bandeng di Kabupaten Indramayu, menganalisis daya saing industri bandeng di Kabupaten Indramayu, dan merumuskan strategi kebijakan untuk meningkatkan daya saing industri bandeng di Kabupaten Indramayu. Metode yang digunakan pada penelitian ini adalah model Porter's diamond, analisis gap, dan analytical hierarchy process (AHP). Hasil analisis menunjukkan bahwa Kabupaten Indramayu dapat meningkatkan daya saing dengan memerhatikan beberapa faktor, yaitu peningkatan kualitas sumber daya manusia, terciptanya kemudahan akses sumber daya modal, penguatan infrastruktur, serta kemudahan kerja sama dengan industri pendukung dan industri terkait. Faktor utama adalah sumber daya modal, dengan aktor dan tujuan utama adalah pelaku usaha dan meningkatkan pendapatan pelaku usaha. Strategi alternatif berdasarkan prioritas secara berturut-turut adalah strategi meningkatkan produksi, strategi penguatan infrastruktur, strategi peningkatan kerja sama antar stakeholder, strategi penyuluhan, serta strategi perbaikan regulasi.

Kata kunci: AHP, analisis gap, daya saing, industri bandeng, model Porter's diamond
\end{abstract}

\section{PENDAHULUAN}

Ikan merupakan salah satu komoditas perdagangan yang mengalami perkembangan perdagangan cukup pesat sejalan dengan meningkatnya jumlah penduduk dunia. Sesuai dengan pendapat Natalia dan Nurozy (2012), bahwa jumlah konsumsi ikan dunia, baik ikan segar maupun ikan olahan, sangat besar dan ikan tidak hanya dikonsumsi oleh manusia tetapi juga digunakan untuk bahan baku pakan ternak. Sejalan dengan hal tersebut, sektor perikanan juga berperan penting dalam pembentukan PDB nasional. Pertumbuhan 
PDB perikanan periode 2013-2014 berada di atas pertumbuhan PDB nasional dan sektor kelompok pertanian. Pertumbuhan tersebut menunjukkan adanya peningkatan daya beli (purchasing power) para pelaku dalam sektor kelautan dan perikanan dibandingkan sektor kelompok pertanian dan nasional. Sektor perikanan tangkap dan budidaya perikanan dipilih menjadi tumpuan utama Kementerian Kelautan dan Perikanan karena produksinya selalu mendominasi dibandingkan sektor lain. Sebagai bagian dari industri perikanan nasional, perikanan budidaya terus berkembang walaupun masih menghadapi berbagai masalah, di antaranya terkait dengan implementasi kebijakan tata ruang, prasarana saluran irigasi yang terbatas, ketersediaan dan distribusi induk dan benih unggul masih terbatas, harga pakan yang mahal, serta serangan hama, penyakit, dan pencemaran yang memengaruhi kualitas lingkungan perikanan budidaya.

Total produksi perikanan budidaya di Indonesia pun terus meningkat secara signifikan. Pada periode 2011-2014, total produksinya melampaui target produksi meskipun pada tahun 2015 realisasi produksi hanya hampir mencapai target. Nilai total produksi budidaya pun terus mengalami peningkatan dari tahun 2011 hingga tahun 2015, meskipun nilai total produksi tahun 2015 tidak dapat mencapai target (SIMAqua, 2015). Menurut data BPS perusahaan perikanan budidaya pun terus meningkat pada periode 20102014. Berdasarkan jenis budidayanya, perusahaan budidaya jenis tambak adalah yang terbesar dibandingkan jenis pembenihan, air tawar, dan laut.

Dirjen Perikanan Budidaya menyatakan bahwa ikan bandeng adalah salah satu pilihan untuk meningkatkan produksi perikanan budidaya yang belum dilakukan secara optimal karena kendala keterbatasan lahan, padahal harganya terjangkau, bergizi, budidayanya mudah dilakukan, dan dapat meningkatkan pendapatan masyarakat pesisir. Budidaya ikan bandeng sendiri dilakukan di tambak dengan media air payau. Menurut Dahuri (2010), Indonesia memiliki potensi lahan tambak terluas di dunia, di mana lebih dari 1,22 juta hektar tersebar di seluruh provinsi. Sebesar 452.901 hektar atau 27 persen lahan tersebut telah dibangun tambak. Ikan bandeng (Chanos chanos), yang merupakan satu-satunya spesies yang masih ada dari familia Chektarenidae, adalah salah satu jenis ikan payau yang memiliki rasa yang spesifik dan dikenal di Indonesia bahkan di dunia. Ikan bandeng atau milkfish menjadi komoditas unggulan di Pulau
Jawa, seperti sate bandeng khas Banten, bandeng presto khas Semarang, dan bandeng cabut duri khas Sidoarjo. Budidaya ikan bandeng di daerah Banten, Jawa Barat, Jawa Tengah, dan Jawa Timur dilakukan dengan sistem budidaya tambak dan budidaya laut. Produksi bandeng meningkat setiap tahunnya dengan rata-rata kenaikan produksi yang signifikan, yaitu kenaikan rata-rata sebesar 10,84 persen. Produksi bandeng nasional pada periode 2009-2013 secara berturut-turut sebesar 328.288 ton, 421.757 ton, 467.449 ton, 518.939 ton, dan 626.878 ton (DJ PB-KKP, 2014).

Provinsi Jawa Barat merupakan salah satu sentra tambak di Indonesia, di mana daerah Pantai Utara (Pantura) Jawa, yakni Indramayu, merupakan salah satu kabupaten di Provinsi Jawa Barat yang telah ditetapkan oleh Kementerian Kelautan dan Perikanan (KKP) Republik Indonesia sebagai lokasi pengembangan minapolitan berdasarkan SK Menteri Kelautan dan Perikanan RI Nomor KEP. 32/MEN/2010 tentang Penetapan Kawasan Minapolitan. Lokasi kawasan minapolitan di Kabupaten Indramayu yaitu di daerah perikanan budidaya di Desa Karang Anyar, Kecamatan Pasekan (Tambak), dan Desa Krimun, Kecamatan Losarang (Kolam); perikanan tangkap di Desa Karangsong, Kecamatan Indramayu; P2HP di Desa Kenanga, Kecamatan Sindang; Garam di Kecamatan Losarang. Penetapan Lokasi Pengembangan Kawasan Minapolitan berdasarkan Keputusan Bupati Nomor 523/kep. 24-Diskanla/2011 dan Pembentukan Kelompok Kerja (POKJA) berdasarkan Keputusan Bupati Nomor 523.05/ Kep.123G-Diskanla/2011. Komoditas unggulan yang dikembangkan yaitu udang vaname, udang windu, dan bandeng (SEMILIR, 2014).

Daya saing bandeng Jawa Barat masih lebih rendah dibandingkan dengan Jawa Tengah dan Sulawesi, sehingga daya saing bandeng di Jawa Barat perlu ditingkatkan. Jawa Barat belum mengeksplorasi sumber daya yang dimiliki secara optimal. Salah satu upaya yang dapat dilakukan untuk mengoptimalkan eksplorasi tersebut adalah dengan meningkatkan daya saing Kabupaten Indramayu karena Kabupaten Indramayu berkontribusi sebanyak 53,75 persen dari total produksi budidaya bandeng Jawa Barat atau sebesar 50.466,67 ton. Produksi bandeng dari budidaya tambak di Kabupaten Indramayu sebagai sentra tambak selalu melampaui target setiap tahunnya. Kecamatan Pasekan dan Kecamatan Cantigi merupakan produsen bandeng yang paling produktif. Produksi tambak di dua kecamatan tersebut dapat dilihat pada Tabel 1. 
Tabel 1. Produksi Bandeng Budidaya Tambak di Kabupaten Indramayu (dalam ton)

\begin{tabular}{cccccccc}
\hline \multirow{2}{*}{ No } & \multirow{2}{*}{ Kecamatan } & \multicolumn{3}{c}{2013} & \multicolumn{2}{c}{2014} & \multicolumn{2}{c}{$\mathbf{2 0 1 5}$} \\
\cline { 3 - 8 } & & Target & Capaian & Target & Capaian & Target & Capaian \\
\hline 1 & Pasekan & 12.140 & $17.532,65$ & 12.140 & 15.483 & 14.354 & $19.547,90$ \\
2 & Cantigi & 6.850 & $11.299,38$ & 6.850 & $10.674,08$ & 7.535 & $16.294,21$ \\
\hline
\end{tabular}

Sumber: Diskanla Kabupaten Indramayu, 2016 (Data diolah).

Sebanyak 64,95 persen produksi tambak bandeng di Kabupaten Indramayu pada tahun 2015 dihasilkan oleh Kecamatan Pasekan dan Cantigi. Bandeng yang dihasilkan dari tambak di Pasekan umumnya bandeng yang akan didistribusikan dan dipasarkan lintas provinsi, sedangkan sebagian besar bandeng yang diproduksi di Cantigi adalah bandeng yang dikhususkan untuk perayaan imlek. Analisis strategi peningkatan daya saing di Kabupaten Indramayu diharapkan dapat meningkatkan produktivitas tambak bandeng di Jawa Barat, khususnya Kabupaten Indramayu. Tujuan dari penelitian ini adalah mengidentifikasi kondisi faktual perikanan bandeng di Kabupaten Indramayu, menganalisis daya saing industri bandeng di Kabupaten Indramayu, dan merumuskan strategi kebijakan untuk meningkatkan daya saing industri bandeng di Kabupaten Indramayu dengan menggunakan analisis model Porter's diamond, analisis gap, dan analytical hierarchy process (AHP).

\section{METODE}

Penelitian ini dilaksanakan di Kabupaten Indramayu untuk mengumpulkan data primer dan data sekunder. Data primer diperoleh dari sumber pertama melalui wawancara terstruktur kepada para responden dengan menggunakan kuesioner. Responden merupakan narasumber ahli yang dipilih berdasarkan pertimbangan kepakaran, pengalaman praktis, dan pemangku kepentingan. Data sekunder diperoleh dari berbagai sumber melalui studi literatur, instansi dan kelembagaan lainnya, serta rujukan dari internet. Data ini berupa hasil kajian pustaka, laporan, dokumentasi, arsip, dan lain-lain. Teknik pengumpulan data yang dilakukan adalah observasi, in-depth interview, dan melakukan studi pustaka. Teknik penentuan responden dilakukan secara sengaja (purposive sampling) yang dianggap pakar/ahli dalam sektor perikanan bandeng, khususnya budidaya tambak. Narasumber ahli dalam penelitian ini adalah pelaku usaha, Dinas Kelautan dan Perikanan Kabupaten Indramayu, dan akademisi.

Teknik pengolahan dan analisis data yang dilakukan penelitian ini adalah menganalisis lingkungan internal dan eksternal industri, menyusun hasil analisis dalam kerangka Porter's Diamond, melakukan analisis gap, dan menetapkan prioritas strategi yang direkomendasikan menggunakan
Analytical Hierarchy Process (AHP). Porter (1990) mendefinisikan empat atribut (determinan) yang menentukan keunggulan kompetitif organisasi yang disebut Porter's diamond model. Keempat determinan tersebut adalah kondisi faktor; kondisi permintaan; industri terkait dan pendukung; serta strategi perusahaan, struktur, dan persaingan. Analisis gap digunakan untuk mengevaluasi kinerja perusahaan dan merupakan langkah yang penting dalam tahapan perencanaan maupun tahapan evaluasi kinerja. Gap mengindikasikan adanya suatu perbedaan antara satu hal dengan lainnya pada kondisi saat ini dengan kondisi seharusnya (ideal). Proses hierarki analitik (analytical hierarchy process) merupakan metode yang digunakan untuk memecahkan masalah yang tidak terstruktur, strategis dan dinamik menjadi sebuah bagian-bagian dan tertata dalam suatu hierarki.

\section{HASIL DAN PEMBAHASAN}

\section{Analisis Lingkungan Industri Bandeng di Kabupaten Indramayu}

Kabupaten Indramayu merupakan kawasan yang terletak di wilayah Pantura Jawa Barat. Secara geografis, Kabupaten Indramayu terletak pada $107^{\circ} 52^{\prime}$ - 108 $36^{\prime}$ Bujur Timur dan 6 $6^{\circ} 15^{\prime}-6^{\circ} 40^{\prime}$ Lintang Selatan. Luas wilayah adalah 204.011 ha dengan panjang garis pantai 147 kilometer yang membentang sepanjang Pantura antara Cirebon hingga Subang dan terdapat 36 desa pantai dari 11 kecamatan.

Wilayah administrasi pemerintah Kabupaten Indramayu saat ini terdiri dari 31 Kecamatan, 309 Desa, dan 8 Kelurahan. Sektor perikanan dan kelautan Kabupaten Indramayu telah teruji ketahanannya terhadap krisis ekonomi dan memiliki segmen usaha beragam, baik on farm maupun off farm yang dilakukan mulai dari penerapan skala teknologi sederhana hingga intensif dengan peluang penyerapan tenaga kerja yang terdiri dari berbagai jenis kelamin, umur, dan pendidikan. Sektor pemasaran produk perikanan dan kelautan pun memiliki akses pasar yang luas sejalan dengan peningkatan kesadaran masyarakat dalam mengkonsumsi ikan ataupun untuk kebutuhan industri kosmetik dan kesehatan untuk memenuhi permintaan dalam dan luar negeri.

Data statistik perikanan dan kelautan Provinsi Jawa Barat menunjukkan bahwa total luas lahan 
Tabel 2. Produksi Bandeng di Kabupaten Indramayu (dalam ton)

\begin{tabular}{cccccc}
\hline & \multicolumn{5}{c}{ Tahun } \\
\cline { 2 - 6 } & $\mathbf{2 0 1 1}$ & $\mathbf{2 0 1 2}$ & $\mathbf{2 0 1 3}$ & $\mathbf{2 0 1 4}$ & $\mathbf{2 0 1 5}$ \\
\hline Produksi(ton) & $39.183,25$ & $39.472,72$ & $50.466,67$ & $48.175,62$ & $55.181,05$ \\
\hline Sumber: Diskanla Kabupaten Indramayu, 2016 (Data diolah).
\end{tabular}

tambak di Kabupaten Indramayu pada tahun 2010 mencapai 22.626 ha, dengan luas yang sudah dijadikan tambak mencapai 20.384 ha. Luasan tersebut menjadi luasan tambak terbesar di Jawa Barat (KKP, 2013). Kegiatan memelihara ikan bandeng sudah ada sejak lama di Kabupaten Indramayu. Menurut Darmansah et al. (2016), kegiatan budidaya yang dilakukan masih banyak yang bersifat monokultur, yaitu hanya memelihara satu jenis komoditi saja. Guna meningkatkan pendapatan tambak, dilakukan pula polikultur. Kegiatan polikultur yang sudah mulai banyak dilakukan adalah budidaya bandeng dengan rumput laut.

Potensi tambak seluas 22.626 ha berada di Kecamatan Krangkeng, Karangampel, Juntiyuat, Balongan, Indramayu, Pasekan, Sindang, Arahan, Cantigi, Lohbener, Losarang, Kandanghaur, Sukra, dan Patrol, dengan kecamatan yang memiliki tambak paling luas, yaitu Kecamatan Indramayu, Pasekan, Cantigi, dan Losarang. Umumnya, tambak diproduktifkan dengan budidaya bandeng, nila, udang windu, dan udang vaname. Teknologi proses budidaya yang diterapkan adalah teknologi sederhana, madya, semi intensif, dan intensif. Komoditi budidaya yang produksinya paling mendominasi adalah bandeng. Dengan produksi yang selalu melampaui target setiap tahunnya. Produksi bandeng di Kabupaten Indramayu pada tahun 2011-2015 dapat dilihat pada Tabel 2.

Kawasan industri tambak bandeng di Kabupaten Indramayu, Jawa Barat telah ditetapkan oleh Kementerian Kelautan dan Perikanan sebagai lokasi pengembangan minapolitan berdasarkan SK Menteri Kelautan dan Perikanan RI Nomor KEP.32/MEN/2010. Kebijakan tersebut seiring dengan pengembangan pembangunan perikanan berdasarkan zonasi yang bertujuan menciptakan percepatan pembangunan perikanan dan kelautan secara terintegrasi dengan melibatkan berbagai sektor.

\section{Analisis Model Porter's Diamond}

Analisis keunggulan kompetitif dengan menggunakan model Porter's Diamond dilakukan melalui empat komponen utama yang saling menguatkan, yaitu kondisi faktor, kondisi permintaan, industri terkait dan pendukung, serta strategi perusahaan, struktur dan persaingan. Lalu ditambah dengan dua komponen pendukung, yaitu peran pemerintah dan kesempatan yang akan dijelaskan secara deskriptif.

\section{Kondisi Faktor di Kabupaten Indramayu}

\section{a. Sumber daya alam}

Kabupaten Indramayu berada di Provinsi Jawa Barat. Terletak membujur pada posisi $107^{\circ} 52^{\prime}$ $108^{\circ} 36^{\prime}$ Bujur Timur dan $6^{\circ} 15^{\prime}-6^{\circ} 40^{\prime}$ Lintang Selatan. Sebelah utara berbatasan dengan Laut Jawa, sebelah timur dengan Kabupaten Cirebon dan Laut Jawa, serta sebelah selatan berbatasan dengan Kabupaten Majalengka, Kabupaten Sumedang dan Kabupaten Cirebon, serta sebelah barat berbatasan dengan Kabupaten Subang. Wilayah Kabupaten Indramayu memiliki luas 204.011 ha dan panjang garis pantai $147 \mathrm{~km}$. Terdapat 36 desa pantai dari 11 kecamatan.

Secara hidrologi, sumber air di Kabupaten Indramayu meliputi air permukaan dan air tanah. Air permukaan berupa sungai dan air genangan yang merupakan daerah aliran sungai (DAS), sedangkan air tanah terdiri dari air tanah bebas dan air tanah tertekan yang dieksploitasi melalui sumur-sumur pompa. Kabupaten Indramayu merupakan daerah hilir dari aliran sungai-sungai yang sangat potensial sebagai sumber air bagi kebutuhan masyarakat untuk usaha pertanian, industri, dan bahan baku air bersih.

Ketinggian wilayah Kabupaten Indramayu umumnya berkisar antara 0-18 mdpl, di mana wilayah dataran rendah berkisah antara 0-6 mdpl yang berupa rawa, tambak, sawah, pekarangan, dan lainlain. Dataran rendah menjadi bagian terluas dari total wilayah di sebelah utara dan timur. Seluas 201.285 ha atau 96,03 persen permukaan tanahnya berupa dataran dengan kemiringan 0-2 persen. Secara geomorfologi, wilayah Kabupaten Indramayu terbagi menjadi daerah perbukitan rendah bergelombang dan dataran rendah. Kabupaten Indramayu termasuk beriklim tropis tipe $D$ (iklim sedang) dengan karakter suhu udara berkisar antara $22,9^{\circ} \mathrm{C}-30^{\circ} \mathrm{C}$ dengan suhu udara rata-rata tertinggi mencapai $32^{\circ} \mathrm{C}$, kelembaban udara 70-80 persen, curah hujan rata-rata tahunan sebesar $1.587 \mathrm{~mm} /$ tahun dengan jumlah hari hujan sebanyak 91 hari, curah hujan tertinggi sekitar $2.008 \mathrm{~mm}$ dan jumlah hari hujan sebanyak 84 hari, sedangkan curah hujan terendah sekitar $1.063 \mathrm{~mm}$ dengan jumlah hari hujan 68 hari, serta angin barat dan angin timur bertiup bergantian setiap 5-6 bulan sekali (Bappeda Kabupaten Indramayu, 2010).

Hingga tahun 2014, potensi lahan tambak di Kabupaten Indramayu, telah mencapai 22.626 ha. Luas lahan tambak bandeng di Kabupaten Indramayu mencapai $12.065,08$ ha, di mana seluas 3.223 ha 
terdapat di Kecamatan Pasekan dan 4.092,95 ha terdapat di Kecamatan Cantigi. Umumnya lahan tambak tersebut dimanfaatkan untuk produktivitas budidaya ikan bandeng, nila, udang windu, dan udang vaname. Kabupaten Indramayu menghasilkan bandeng melalui budidaya tambak sebesar 50.466,67 ton atau berkontribusi sebesar 53,75 persen bagi produksi bandeng di Jawa Barat. Namun produksi di Kabupaten Indramayu mengalami penurunan pada tahun 2014 dengan produksi sebesar 48.175,62 ton dan kembali naik pada tahun 2015 dengan produksi sebesar 55.181,05 ton. Produksi bandeng di Kabupaten Indramayu didominasi oleh Kecamatan Pasekan dan Kecamatan Cantigi dengan produksi pada tahun 2015 berturut-turut sebesar 19.547,90 ton dan 16.294,21 ton.

\section{b. Sumber daya manusia}

Menurut Kalangi (2015), sumber daya manusia adalah faktor yang sangat sentral dalam organisasi. Hal tersebut menuntut setiap organisasi mendapatkan manusia yang berkualitas dan produktif untuk menjalankan organisasi. Secara demografis, Kabupaten Indramayu yang memiliki penduduk 2.001.520 jiwa, terdiri dari 49.78 persen laki-laki (996.448 jiwa) dan 50,22 persen perempuan (1.005.072 jiwa) (SIAK Provinsi Jawa Barat, 2011). Sumber daya manusia yang terdapat di Kabupaten Indramayu untuk industri bandeng dapat dikatakan mencukupi karena jumlah penduduk yang banyak di kawasan tambak dan sebagian besar pekerjaannya adalah petani tambak. Sumber daya manusia untuk subsektor perikanan di Kabupaten Indramayu sendiri dikelola dalam kelompok. Hingga tahun 2015, jumlah kelompok tenaga kerja subsektor perikanan mencapai 309 kelompok, di mana setiap kelompok memiliki anggota berkisar delapan hingga dua ratus orang. Para pembudidaya bandeng di Kabupaten Indramayu bekerja dalam kelompok yang biasanya dikelola di setiap kecamatan. Kelompok umumnya dipimpin oleh pemilik lahan tambak. BPS (2017) menyatakan bahwa semua penduduk Kabupaten Indramayu telah mengenyam pendidikan dasar, sebanyak 76,02 persen hingga pendidikan menengah, 60.81 persen hingga pendidikan atas, dan sebesar 12,43 persen yang menuntaskan pendidikan hingga jenjang perguruan tinggi. Hal tersebut menunjukkan bahwa sumber daya manusia di Kabupaten Indramayu telah memiliki pengetahuan yang dapat menunjang kinerjanya.

Tenaga kerja yang dibutuhkan dalam subsektor perikanan di Kabupaten Indramayu tidak hanya dalam bidang budidaya di tambak saja, namun juga yang terampil dan menguasai teknik budidaya, menguasai manajemen produksi, pemasaran, dan memiliki jiwa wirausaha, serta memiliki kemampuan menjadi pemasar lokal dan domestik untuk dapat meningkatkan daya saingnya. Para tenaga kerja akan menjalankan perannya masing-masing pada tiap tahapan produksi budidaya di tambak. Tenaga kerja dalam kegiatan budidaya bandeng di Kabupaten Indramayu terdiri dari tenaga kerja untuk proses pemeliharaan dan tenaga kerja untuk pemanenan.

Pemerintah daerah Kabupaten Indramayu, khususnya Dinas Perikanan dan Kelautan (Diskanla) Kabupaten Indramayu, menganggap bahwa kualitas sumber daya manusia harus didahulukan sebelum diberikan fasilitas maupun teknologi untuk kegiatan penambakan bandeng. Hal tersebut dikarenakan fasilitas dan teknologi yang mumpuni sekalipun tidak dapat dimanfaatkan dengan baik jika operator, yaitu manusia, tidak memiliki kemampuan yang mumpuni pula.

\section{Sumber daya modal}

Menurut Listyawan (2011), modal adalah uang yang digunakan sebagai pokok berdagang, melepas uang dan sebagainya ataupun harta benda (uang, barang, dan sebagainya) yang dapat digunakan untuk menghasilkan sesuatu yang menambah aset. Modal sangat diperlukan bagi jalannya kegiatan industri bandeng. Indikator kemudahan pinjaman, modal patungan, efektivitas pemakaian modal, bunga dan jangka waktu pengembalian pinjaman, serta peranan modal dapat mengukur pengaruh modal. Kemampuan finansial industri bandeng di Kabupaten Indramayu sangat ditentukan oleh para pembudidaya itu sendiri sebagai pemilik dan pengelola tambak.

Modal menjadi aspek yang penting bagi pelaku budidaya tambak maupun pemerintah daerah di Kabupaten Indramayu. Saat ini modal yang banyak didapatkan dari dana para pembudidaya sendiri, baik dengan mengeluarkan dana pribadi maupun melakukan kemitraan. Kemitraan dilakukan misalnya dengan bakul, tengkulak, pengepul, ataupun industri pakan. Para pembudidaya melakukan kerja sama dengan bakul, tengkulak maupun pengepul dikarenakan untuk melakukan pinjaman kurang dari Rp50 juta tidak memerlukan jaminan. Sedangkan kerja sama pembudidaya dengan produsen pakan dilakukan melalui sistem pembayaran saat setelah panen. Jadi produsen pakan memberikan pakan terlebih dahulu saat musim budidaya dimulai dan pembayaran dilakukan saat pembudidaya telah melakukan panen. Modal yang cukup tinggi dibutuhkan karena biaya pakan dan pemanenan membutuhkan modal yang sangat besar. Misalnya saja untuk satu siklus bandeng imlek, membutuhkan modal sekitar Rp3 miliar dan akan menghasilkan sekitar seratus ton bandeng. Dengan luas tambak 
satu hingga tiga hektar, di mana per hektar akan menghasilkan tiga ton bandeng untuk tiap siklusnya. Namun saat ini, Diskanla Kabupaten Indramayu, khususnya divisi Pendampingan Nelayan Kecil telah melakukan upaya modal perbankan bagi para petani tambak. Upaya tersebut dilakukan dengan memberikan bantuan dalam kemudahan sertifikasi lahan tambak untuk mengubah AJP menjadi sertifikat agar lebih mudah diajukan pada perbankan. Sehingga di masa mendatang para pembudidaya, khususnya penambak kecil, mampu mendapatkan pinjaman modal dengan mudah.

\section{d. Infrastruktur}

Infrastruktur merupakan faktor utama penggerak pertumbuhan ekonomi. Hasil riset Demurger (2000), menyatakan bahwa objek pembangunan infrastruktur transportasi yang terorganisir di antara 24 provinsi di Tiongkok merupakan faktor utama penentu pesatnya laju pertumbuhan ekonomi negara tersebut dalam waktu delapan tahun terakhir. Di Indonesia, sektor infrastruktur transportasi merupakan sektor paling berpengaruh terhadap laju pertumbuhan ekonomi Indonesia setelah sektor industri. Kondisi infrastruktur di Kabupaten Indramayu saat ini terbilang cukup baik karena sudah banyak pembangunan sarana dan prasarana yang dilakukan. Infrastruktur yang dominan adalah transportasi darat, di mana semua kegiatan pra produksi hingga pascapanen dilakukan melalui jalur darat. Namun bagi sebagian daerah yang kondisi infrastrukturnya kurang baik harus melalui jalur transportasi laut.

Pembangunan infrastruktur di Kabupaten Indramayu lebih diutamakan pada pembangunan dan penguatan jalan darat. Hingga saat ini belum ada perencanaan pembangunan lain, seperti jalur kereta api. Transportasi darat dinilai sangat mudah dan praktis untuk dilalui sehingga para pelaku usaha mengharapkan pembangunan dan penguatan jalan darat yang merata di setiap wilayah. Rencana pemerintah daerah saat ini adalah melakukan perbaikan jalan dan perbaikan saluran tambak. Dari total panjang pertambakan di Kabupaten Indramayu sepanjang 468,6 kilometer, sepanjang 180,6 kilometer telah diperbaiki dan layak digunakan, sedangkan sepanjang 288 kilometer dalam keadaan rusak atau tidak layak digunakan (Sanjaya, 2016).

Saluran tambak yang dalam kondisi kurang baik dapat menggenangi jalan darat sehingga mengganggu aktivitas para pelaku tambak. Para pelaku tambak umumnya enggan melalui jalan yang sulit. Hal tersebut dikarenakan jalan yang kurang baik dapat menyebabkan guncangan pada bandeng hasil panen yang diangkut. Guncangan tersebut dapat menyebabkan kualitas bandeng menurun.
Kualitas bandeng yang menurun pun dapat membuat harga bandeng menjadi lebih rendah sehingga pendapatan maupun keuntungan yang didapatkan oleh pembudidaya akan berkurang.

\section{e. Sumber daya air}

Air dan listrik berperan strategis dalam kegiatan pembangunan, baik secara nasional maupun di daerah. Energi listrik adalah salah satu energi yang sangat dibutuhkan oleh perusahaan, baik secara komersial maupun non komersial (Fitriantie dan Wahyu, 2016). Industri bandeng, khususnya tambak, di Kabupaten Indramayu hanya membutuhkan air sebagai sumber daya utama karena sistem budidaya yang dilakukan masih bersifat tradisional. Kedalaman air yang diperlukan sekitar 1,5 meter untuk setiap tambak. Air yang diberdayakan dalam tambak umumnya berasal dari saluran primer dan sekunder, seperti air payau atau sungai payau. Bagi pemenuhan tambak, perlakuan yang harus dilakukan adalah penguatan dan perawatan insfrastruktur saluran air yang dilakukan secara berkala.

\section{Kondisi Permintaan di Kabupaten Indramayu}

Kondisi permintaan menunjukkan tingkat minat konsumen maupun pasar terhadap ikan bandeng. Kualitas komoditas yang baik akan meningkatkan permintaan terhadap komoditas tersebut. Permintaan yang tinggi karena kualitas yang baik menunjukkan bahwa komoditas tersebut memiliki daya saing yang tinggi pula. Standar atau kualitas mutu yang baik yang diharapkan oleh konsumen maupun pasar akan menimbulkan kompetisi antar perusahaan atau industri. Tingkat konsumsi bandeng nasional berdasarkan data Susenas - BPS (2014) adalah sebesar 1,40 kg/kapita. Serapan pasar ikan bandeng paling tinggi ditunjukkan oleh Provinsi Sulawesi Selatan sebesar 74.839,75 ton, lalu diikuti beberapa provinsi lain seperti Jawa Tengah sebesar 50.916,96 ton dan Jawa Barat sebesar 46.457,58 ton.

Rendahnya tingkat permintaan tersebut dikarenakan tingkat konsumsi ikan yang rendah yang disebabkan oleh beberapa faktor, di antaranya adalah kurangnya pemahaman mayarakat tentang gizi dan manfaat protein ikan, rendahnya suplai ikan khususnya ke daerah pedalaman karena masalah distribusi pemasaran, teknologi pengolahan maupun pengawetan yang belum berkembang guna memenuhi keinginan konsumen, serta sarana pemasaran dan distribusi yang masih terbatas secara kualitas maupun kuantitas. Dapat dikatakan bahwa faktor konsumsi ikan dapat dipengaruhi oleh produksi, ketersediaan, dan distribusi ikan. Peningkatan konsumsi ikan perlu dilakukan pada semua lapisan masyarakat dengan promosi melalui komunikasi, informasi, dan edukasi 
untuk meningkatkan kesadaran masyarakat akan pentingnya konsumsi ikan.

Permintaan bandeng dari Kabupaten Indramayu sebagian besar berasal dari Jawa Barat dan DKI Jakarta. Saat ini, tambak bandeng di Kabupaten Indramayu menghasilkan dua jenis produk bandeng, yaitu bandeng konsumsi dan bandeng imlek. Bandeng konsumsi umumnya berukuran 1:3 atau satu kilogram berisi tiga ekor bandeng, sedangkan bandeng imlek berukuran 1:1 atau satu kilogram berisi satu ekor bandeng. Permintaan bandeng konsumsi selalu tinggi saat musim panen. Permintaan umumnya berasal dari Jakarta lalu daerah-daerah lain di Jabodetabek, seperti Bekasi, Bogor, Cikarang, dan Ciputat. Permintaan bandeng imlek dikhususkan hanya saat perayaan imlek saja, yaitu bulan Februari. Harga bandeng saat imlek pun tidak stabil, di mana terjadi lonjakan namun tidak signifikan. Menurut Darmansah et al. (2016), harga bandeng ukuran konsumsi bervariasi mulai Rp17.000 hingga Rp20.000 per kilogram. Sedangkan untuk bandeng imlek dengan ukuran yang besar dapat mencapai harga Rp40.000 per kilogram (Toiskandar, 2017). Permintaan bandeng imlek utamanya berasal dari Jakarta.

\section{Kondisi Industri Pendukung dan Industri Terkait di Kabupaten Indramayu}

Industri yang terlibat dan turut mendukung berjalannya industri bandeng memiliki peran yang sangat penting dan tidak dapat diabaikan. Industri pendukung meliputi industri benih dan industri pakan, sedangkan industri terkait meliputi industri alat berat dan perbankan. Setiap industri memiliki peran masing-masing dalam menunjang daya saing industri bandeng di Kabupaten Indramayu, Jawa Barat.

Industri benih berperan menyediakan benih berkualitas baik agar menghasilkan bandeng dengan kualitas sesuai permintaan konsumen maupun pasar. Produksi dan kualitas benih bandeng atau nener yang baik akan mendukung peningkatan produksi industri bandeng. Dukungan benih harus selalu tersedia dengan cukup, baik secara kualitas, kuantitas, dan tepat waktu sesuai kebutuhan pembudidaya bandeng. Data yang dirangkum detikFinance (2015) menyatakan bahwa peningkatan produksi nener dari tahun 2010 hingga tahun 2014 mengalami peningkatan yang cukup signifikan, yakni sebesar 10,8 persen atau dari 2,4 miliar ekor menjadi 3,2 miliar ekor, namun sebanyak 15 persen nener diekspor ke Filipina. Pembenih nener diharuskan menerapkan cara pembenihan ikan yang baik (CPIB) sesuai Standar Nasional Indonesia (SNI) agar dapat menghasilkan nener berkualitas dengan jumlah yang mencukupi. Penyediaan induk unggul bandeng untuk nener bermutu secara kontinu juga penting untuk diperhatikan. Jenis, kualitas, dan cara pemberian pakan benih yang berkualitas selama masa pembenihan pun penting untuk menghasilkan nener yang berkualitas. Saat ini, sentra nener paling besar terdapat di Bali, khususnya di daerah Gondola. Benih bandeng (nener) yang digunakan pembudidaya di Kabupaten Indramayu diperoleh langsung dari tempat pembenihan (hatchery) atau melalui perantara dan hampir keseluruhan nener di Kabupaten Indramayu pun berasal dari Gondola. Ciri benih bandeng yang baik adalah ekor tidak kuncup, sisik tidak rusak, dan gerakan lincah (Darmansah, et al. 2016). Salah satu kecamatan yang memproduksi benih adalah Kecamatan Pasekan, meskipun benih yang dihasilkan masih berkualitas rendah dan harganya lebih mahal, yaitu Rp60 hingga Rp80 per ekor, sedangkan harga benih yang berasal dari Bali seharga Rp27 hingga Rp50 per ekor. Jumlah benih yang dihasilkan pun belum mampu memenuhi permintaan benih di Kecamatan Pasekan sendiri.

Industri pakan sangat berperan pada fase budidaya. Terdapat pakan pemula dan pakan lanjutan, di mana pakan pemula diberikan saat benih berusia satu sampai tiga bulan. Namun lebih banyak pembudidaya yang hanya menggunakan pakan alami yang berupa plankton, lumut atau klekap sebagai pakan pemula dan hanya sekitar 10 persen pembudidaya yang menggunakan pakan buatan. Padahal sebaiknya pakan alami dan pakan buatan diberikan pada bandeng yang sedang dibudidaya karena pakan buatan dapat memenuhi kebutuhan nutrisi benih yang tidak dapat dipenuhi oleh pakan alami sehingga benih dapat tumbuh optimal. Pemberian pakan buatan di tambak dilakukan setelah bandeng berumur satu bulan dengan frekuensi dua kali sehari, yaitu pada pagi dan sore hari. Frekuensi pemberian pakan kemudian ditingkatkan pada saat tiga bulan menjelang panen menjadi tiga kali sehari, yaitu pada pagi, siang, dan sore hari.

Pembudidaya cenderung menggunakan pakan alami karena dapat menekan biaya produksi. Menurut Dhean (2012), pakan alami pun memiliki keunggulan, seperti dapat menjaga kualitas air karena sisa pakan tidak menyebabkan endapan bahan organik di dasar tambak, tidak mudah rusak karena berupa organisme hidup yang beradaptasi dengan lingkungan, serta mudah dicerna, terutama plankton, karena memiliki dinding sel yang tipis. Namun terdapat kondisi yang sering menjadi keluhan pembudidaya, yaitu besarnya FCR (feed consumption rate) atau konversi pakan budidaya bandeng, di mana harga pakan yang mahal tidak sesuai dengan kualitasnya. Hal tersebut membuat para pembudidaya berharap adanya pakan berprotein tinggi dengan harga yang lebih terjangkau.

Industri mesin dan peralatan yang terlibat dalam kegiatan budidaya bandeng di Kabupaten Indramayu adalah alat berat. Alat berat atau ekskavator digunakan saat kegiatan pra budidaya, yaitu saat 
pengerukan bakal tambak. Tambak bandeng terdiri dari beberapa bagian, yaitu inlet (saluran masuk), caren (bingkai tambak yang lebih dalam), serta outlet (saluran keluar). Ekskavator dapat juga berperan dalam pembuatan akses dari jalan utama menuju kawasan tambak.

Kebutuhan finansial saat ini dibantu oleh industri perbankan. Meskipun saat ini peranannya belum dirasakan langsung oleh pembudidaya maupun petani tambak, saat ini Diskanla terus mengupayakan agar dukungan dari bank dapat dirasakan langsung. Salah satu upayanya adalah membantu para pembudidaya maupun petani tambak dalam hal administrasi.

\section{Kondisi Persaingan di Kabupaten Indramayu}

Kondisi persaingan menjadi faktor terakhir yang menentukan daya saing dalam model Porter's Diamond. Dalam skala nasional, industri bandeng di Jawa Barat sebenarnya sudah ideal, namun tetap harus memerhatikan adanya pesaing. Adanya pesaing membuat Jawa Barat harus memiliki tingkat daya saing yang lebih baik, terutama dari pemimpin industri bandeng saat ini, yaitu Jawa Timur. Saat ini Jawa Barat telah menjadi produsen bandeng terbesar ketiga, di mana Kabupaten Indramayu berperan sangat penting dalam mendukung majunya industri bandeng. Industri bandeng di Kabupaten Indramayu sudah berjalan dengan baik melalui peningkatan kualitas yang signifikan tiap tahunnya. Namun saat ini persaingan yang dialami Kabupaten Indramayu adalah dalam hal persaingan pasar dengan bandeng yang berasal dari Kota Surabaya. Harga bandeng yang berasal dari Kabupaten Indramayu akan mengalami penurunan karena jumlah persediaan (stok) bandeng menjadi melimpah sehingga akan menurunkan harga jualnya.

\section{Analisis Gap Industri Bandeng di Kabupaten Indramayu}

Analisis kesenjangan industribandeng di Kabupaten Indramayu, Jawa Barat dilakukan secara deskriptif dari analisis faktor daya saing model Porter's diamond yang telah dibuat. Analisis kesenjangan ini dilakukan untuk menggambarkan bagaimana kondisi yang terjadi saat ini dengan kondisi ideal atau kondisi yang diharapkan sesuai faktor-faktor yang telah dirumuskan dalam model Porter's diamond. Analisis kesenjangan dibuat melalui justifikasi pendapat responden yang merupakan pakar dan praktisi industri tambak bandeng di Kabupaten Indramayu, Jawa Barat serta diperkuat oleh data sekunder yang telah dihimpun dan membandingkan dengan kondisi industri bandeng di Jawa Timur. Hasil analisis gap menunjukkan bahwa faktor sumber daya alam, sumber daya air, energi dan jaringan komunikasi, permintaan produk dan jasa, kelembagaan, serta tingkat persaingan memiliki kesenjangan rendah dengan kondisi ideal. Hal tersebut menunjukkan bahwa

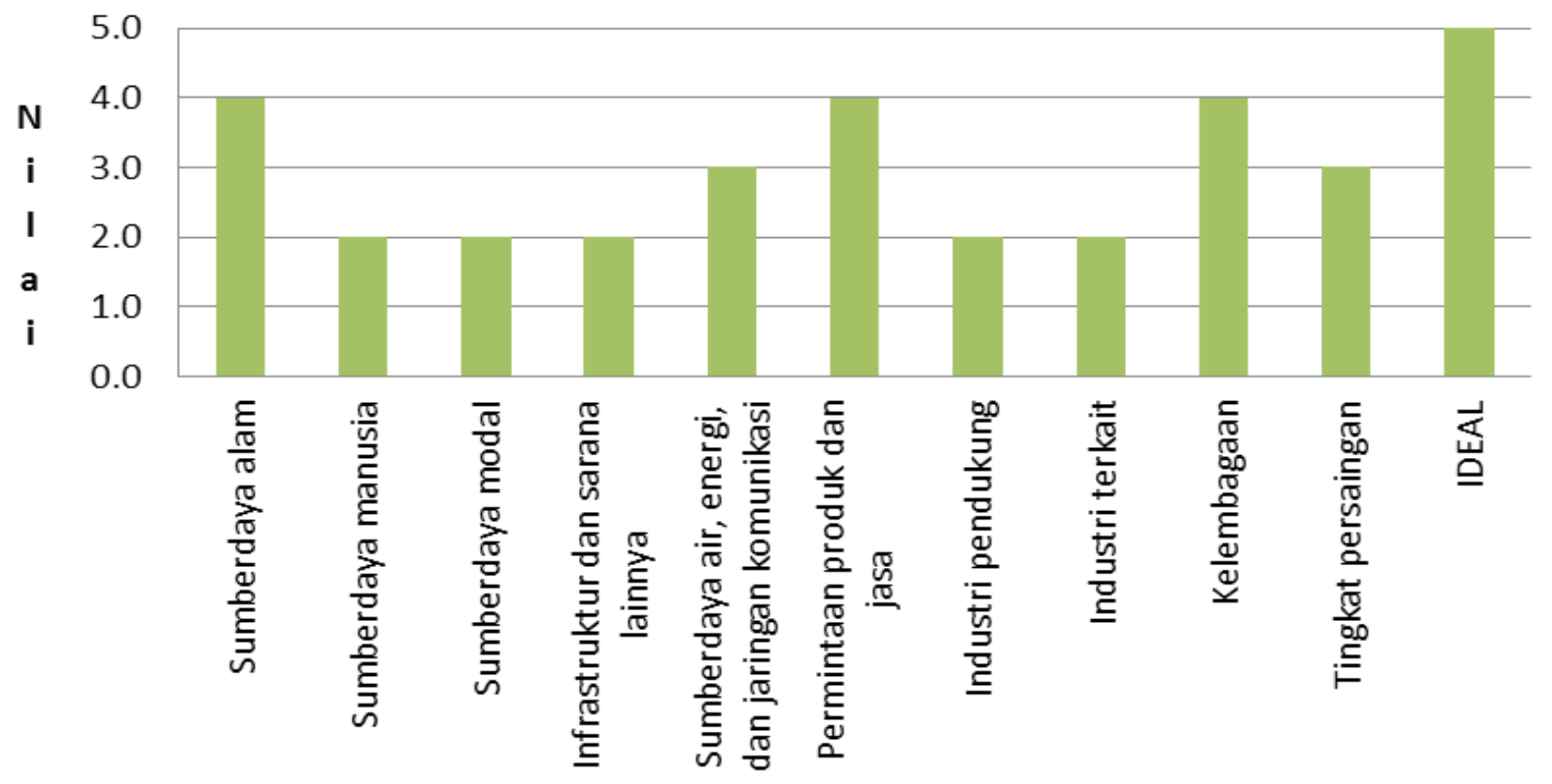

Keterangan:

Faktor dalam Model Porter's Diamond

Nilai 1 = sangat buruk

Nilai 2 = buruk

Nilai 3 = biasa saja

Nilai 4 = baik

Nilai 5 = sangat baik

Gambar 1. Analisis Gap Model Porter's Diamond untuk Peningkatan Daya Saing Industri Bandeng di Kabupaten Indramayu 
faktor-faktor tersebut dalam industri bandeng di Kabupaten Indramayu saat ini dapat dikatakan sudah baik. Berbeda dengan faktor sumber daya manusia, sumber daya modal, infrastruktur dan sarana lainnya, industri pendukung, serta industri terkait yang memiliki kesenjangan cukup besar dengan kondisi ideal. Hal tersebut menunjukkan bahwa faktor-faktor tersebut dalam industri bandeng di Kabupaten Indramayu saat ini perlu diperbaiki dan ditingkatkan kualitasnya. Hasil analisis gap dapat dilihat pada Gambar 1.

\section{Kondisi Faktor}

Kondisi sumber daya alam meliputi iklim, letak geografis, luas lahan dan produktivitas di Kabupaten Indramayu sudah sangat baik (nilai 4). Kondisi alam di Kabupaten Indramayu sangat mendukung untuk jalannya industri bandeng dengan produktivitas tinggi. Menurut Asaf et al. (2013), kondisi ekologis dan geografis Kabupaten Indramayu yang berbatasan dengan Laut Jawa mendukung pengembangan usaha kelautan dan perikanan karena memiliki suhu, iklim, maupun topografi yang sangat sesuai. Hal tersebut terbukti oleh total tambak yang dimiliki Kabupaten Indramayu seluas $22.514,07$ ha dengan komoditas unggulan udang, bandeng, dan rumput laut. Produksi tambak tahun 2011 pun meningkat cukup signifikan dibandingkan tahun 2010, dari sebanyak 82.149 ton menjadi 101.454 ton. Saat ini, dari 31 kecamatan yang ada di Kabupaten Indramayu, sebanyak 12 kecamatan merupakan wilayah pesisir. Potensi tambak seluas 22.625,89 $\mathrm{Ha}$ berada di Kecamatan Krangkeng, Karangampel, Juntiyuat, Balongan, Indramayu, Pasekan, Sindang, Arahan, Cantigi, Lohbener, Losarang, Kandanghaur, Sukra, dan Patrol, dengan kecamatan yang memiliki tambak paling luas, yaitu Kecamatan Indramayu, Pasekan, Cantigi, dan Losarang. Umumnya, tambak diproduktifkan dengan budidaya bandeng nila, udang windu, dan udang vaname. Teknologi proses budidaya yang diterapkan adalah teknologi sederhana, madya, semi intensif, dan intensif.

Sumber daya manusia yang dibutuhkan dalam industri bandeng membutuhkan tenaga kerja yang memiliki keahlian terbatas dan tenaga kerja terdidik. Tenaga kerja dengan keahlian terbatas, yaitu buruh, petani, dan lain-lain, umumnya langsung menggarap lahan tambak. Sedangkan tenaga kerja terdidik dibutuhkan dalam mendukung majunya industri. Sesuai demografi penduduknya, Kabupaten Indramayu telah memiliki kedua jenis tenaga kerja tersebut, namun untuk tenaga kerja terdidik masih sangat kurang keberadaannya (nilai 2). Terdapat beberapa strategi dalam meningkatkan kualitas SDM guna meningkatkan usaha dan pendapatan sekaligus mendukung program pemerintah dalam meningkatkan ekonomi kemasyarakatan, yaitu membangun komunikasi yang efektif antara kelompok pelaku utama perikanan dan pihak pemerintah, meningkatkan dukungan terhadap pengembangan usaha, meningkatkan kualitas dan kuantitas penyuluh perikanan dan tenaga teknis lainnya, meningkatkan dukungan sarana dan prasarana dalam pembinaan, meningkatkan kesadaran pelaku utama perikanan, melaksanakan kegiatan pendidikan dan pelatihan teknis, memfasilitasi penyampaian aspirasi, mengembangkan sistem informasi dan komunikasi, meningkatkan kemampuan SDM sesuai perkembangan teknologi, serta meningkatkan pengawasan dan evaluasi (Azis, 2017).

Sumber daya modal didominasi oleh perorangan, di mana modal didominasi oleh dana individu dalam kelompok tani. Kemudahan peminjaman modal belum dapat dirasakan oleh para pembudidaya dan petani tambak. Ketidakmampuan menyediakan barang jaminan maupun surat-surat kelengkapan menjadi kendala yang sering dihadapi (nilai 2). Hal tersebut akhirnya membuat Diskanla Kabupaten Indramayu akan mengusahakan program untuk membantu para pembudidaya dan petani tambak dalam mengurus surat-surat guna kemudahan peminjaman modal melalui perbankan.

Infrastruktur saat ini sebenarnya sudah banyak dibangun namun kondisinya mulai banyak pula yang mengalami kerusakan dan tak kunjung diperbaiki ataupun masa perbaikan yang cenderung memakan waktu lama (nilai 2). Infrastruktur di kawasan industri bandeng menjadi tanggung jawab Dinas Kelautan dan Perikanan Kabupaten Indramayu, khususnya oleh divisi infrastruktur. Diskanla pun menyadari perlunya perbaikan dan penguatan infrastruktur, khususnya jalan raya yang menghubungkan satu kecamatan dengan kecamatan lainnya yang terlibat dalam industri bandeng.

Sumber daya dan energi yang digunakan saat ini masih didominasi oleh sumber daya air karena budidaya bandeng yang masih bersifat tradisional. Kebutuhan air sangat strategis dalam mendukung industri bandeng yang telah ada. Air yang menunjang tambak bandeng berasal dari sungai payau (nilai 3).

\section{Kondisi Permintaan}

Konsumsi bandeng di Jawa Barat tidak terlalu tinggi dengan nilai serapan pasar di tingkat rumah tangga sebesar 46.457 .58 ton atau sekitar 13 persen dari serapan nasional. Namun permintaan bandeng di Jawa Barat dari Kabupaten Indramayu cukup tinggi, baik untuk permintaan lokal maupun domestik. Peninjauan dari segi permintaan menunjukkan prospek pengembangan bandeng di Kabupaten Indramayu 
tergolong baik karena jumlah permintaan yang semakin meningkat didukung oleh ketersediaan jasa budidaya. Permintaan terbesar bandeng yang diproduksi oleh Kabupaten Indramayu berasal dari Jakarta dan daerah sekitarnya (nilai 4). Guna meningkatkan permintaan bandeng yang berasal dari Kabupaten Indramayu, kualitas mutu bandeng pun sangat penting untuk diperhatikan. Terlebih karena bandeng merupakan produk yang bersifat high perishable atau mudah rusak.

\section{Kondisi Industri Pendukung dan Terkait}

Perusahaan alat berat seperti ekskavator yang terkait kebutuhan di tambak memiliki peran yang sangat penting, khususnya bagi kegiatan pembuatan tambak. Lahan yang akan digarap menjadi tambak akan dikeruk menggunakan ekskavator. Sayangnya akses bagi pembudidaya maupun petani tambak tidak terlalu mudah untuk ini (nilai 2).

Industri pakan dan industri benih menjadi industri pendukung terbesar bagi jalannya industri bandeng di Kabupaten Indramayu. Namun keberadan industri ini, terutama yang lokal, masih sangat sedikit (nilai 2). Saat ini, pasokan benih terbesar masih didapatkan dari industri benih di Bali, sedangkan untuk pasokan pakan masih didapatkan dari sekitar daerah Kabupaten Indramayu. Kedepannya, para pelaku usaha mengharapkan agar tersedia benih dan pakan dengan kualitas baik yang berasal langsung dari Kabupaten Indramayu agar lebih memperpendek rantai pasoknya. Sejalan dengan hal tersebut, Diskanla Kabupaten Indramayu pun telah merencanakan program pembinaan pada masyarakat, khususnya para penambak, agar dapat memproduksi benih dan pakan dengan kualitas yang baik.

Lembaga yang terlibat dalam industri bandeng ini adalah Dinas Kelautan dan Perikanan Kabupaten Indramayu dan lembaga perbankan. Diskanla Kabupaten Indramayu telah banyak merangkul para pembudidaya dan petani tambak agar mendapat penyuluhan, kemudahan akses terhadap sarana dan prasarana, serta kebutuhan finansial yang tidak dapat dilakukan langsung melalui bank (nilai 4). Divisi yang berperan langsung dalam mengayomi para pelaku usaha tersebut adalah divisi Pendampingan Nelayan Kecil.

\section{Kondisi Persaingan}

Industri bandeng di Kabupaten Indramayu berjalan cukup baik, dengan perkembangan yang signifikan tiap tahunnya. Hal tersebut dapat dilihat dengan hasil produksi yang terus meningkat tiap tahunnya, namun yang masih menjadi kendala adalah posisi hasil budidaya tambak bandeng di Indonesia, khususnya di Pulau Jawa, meskipun permintaan selalu tinggi untuk menyerap seluruh hasil produksi (nilai 3). Salah satu pesaing untuk pasar di Jawa Barat adalah Kota Surabaya. Jika Kota Surabaya mengirimkan hasil produksinya ke Kota Jakarta, maka harga bandeng yang berasal dari Kabupaten Indramayu akan mengalami penurunan. Hal tersebut diakibatkan oleh jumlah persediaan (stok) bandeng yang melimpah sehingga akan menurunkan harga jualnya.

Analisis gap dari model Porter's diamond yang dikombinasikan dengan hasil diskusi dengan para pakar menghasilkan lima faktor yang memengaruhi keberhasilan untuk meningkatkan daya saing industri bandeng di Kabupaten Indramayu. Faktor-faktor tersebut telah melalui pertimbangan dari analisis gap, di mana faktor yang memiliki nilai paling rendah atau memiliki kesenjangan terbesar antara kondisi saat ini dengan kondisi ideal yang diharapkan. Besarnya kesenjangan menunjukkan perlunya peningkatan dan perbaikan guna mengembangkan industri bandeng di Kabupaten Indramayu. Kelima faktor tersebut adalah sumber daya manusia, sumber daya modal, infrastruktur, industri pendukung, dan industri terkait.

Faktor-faktor tersebut merupakan sasaran yang menjadi inti permasalahan yang ingin diselesaikan dalam penelitian ini untuk peningkatan daya saing industri bandeng di Kabupaten Indramayu Jawa Barat. Peningkatan daya saing industri bandeng di Kabupaten Indramayu menjadi prioritas dan perlu dilakukan karena banyaknya sasaran yang ingin dicapai oleh para stakeholder yang ada dalam industri tersebut.

Sumber daya manusia menjadi salah satu faktor penting yang memengaruhi peningkatan daya saing industri bandeng di Kabupaten Indramayu. Sumber daya manusia untuk subsektor perikanan di Kabupaten Indramayu sendiri dikelola dalam kelompok. Hingga tahun 2015, jumlah kelompok tenaga kerja subsektor perikanan mencapai 309 kelompok, dan setiap kelompok memiliki anggota berkisar delapan hingga dua ratus orang. Seiring dengan perkembangan teknologi pada kegiatan budidaya tambak bandeng, memerlukan mutu dan kualitas SDM yang terus berkembang untuk terus meningkatkan mutu produksinya.

Modal diperlukan untuk menjalankan kegiatan industri. Pembiayaan atau sumber daya modal pun sangat penting bagi kelangsungan dan pengembangan industri bandeng Kabupaten Indramayu Jawa Barat. Kemampuan finansial industri bandeng di Kabupaten Indramayu sangat ditentukan oleh pelaku tambak dan perbankan.

Ketersediaan infrastuktur untuk mendukung aktivitas industri di kawasan Kabupaten Indramayu harus dilengkapi. Infrastruktur serta sarana dan 
prasarana menjadi roda penggerak pertumbuhan ekonomi, khususnya di Kabupaten Indramayu.

Industri lain yang ikut mendukung berkembangnya industri bandeng di Kabupaten Indramayu adalah industri benih dan industri pakan. Kedua industri tersebut saling terkait dan bermanfaat satu sama lain dalam mendukung jalannya industri bandeng. Industri benih dan pakan tersebut sebaiknya disediakan di Kabupaten Indramayu supaya dapat menghasilkan benih dan pakan yang berkualitas dengan harga yang lebih terjangkau pula.

Industri yang terkait dengan perkembangan industri bandeng di Kabupaten Indramayu adalah industri alat berat dan perbankan. Kedua industri tersebut saling terkait dan bermanfaat satu sama lain dalam mendukung jalannya industri bandeng.

\section{Prioritas Strategi Peningkatan Daya Saing Industri Bandeng di Kabupaten Indramayu}

Proses pengambilan keputusan dengan metode AHP dilakukan secara terstruktur untuk menentukan strategi yang menjadi prioritas bagi peningkatan daya saing industri bandeng Kabupaten Indramayu. Hierarki ditentukan sesuai pendapat enam orang responden pakar atau ahli di bidangnya, baik secara individu maupun kelembagaan. Hal yang harus diperhatikan dalam pengambilan keputusan adalah saat pengambilan data, di mana data diharapkan dapat mendekati nilai yang sesungguhnya. Contohnya dengan menggunakan perbandingan berpasangan yang dilakukan dalam penelitian ini. Perbandingan berpasangan diulang untuk semua elemen dalam setiap level. Elemen dengan bobot paling tinggi adalah pilihan keputusan yang layak diambil. Pengkuantifikasian pendapat kualitatif tersebut dilakukan menggunakan skala penilaian hingga diperoleh nilai pendapat dalam bentuk angka (kuantitatif). Hal tersebut sesuai dengan Saaty (1990) yang menyatakan bahwa skala 1 sampai 9 merupakan skala terbaik dalam mengkuantifikasi pendapat berdasarkan akurasi sesuai nilai RMS (Root Mean Square Deviation) dan MAD (Median Absolute Deviation). Kemudian nilainilai perbandingan kriteria tersebut diolah untuk menentukan peringkat kriteria. Hasil pengolahan nilai-nilai perbandingan kriteria ditunjukkan pada Gambar 2.

Faktor prioritas sebagai penentu utama peningkatan daya saing industri bandeng di Kabupaten Indramayu adalah sumber daya modal dengan bobot 0,269 . Peran modal yang mudah didapatkan tanpa melalui birokrasi yang rumit akan sangat berpengaruh pada peningkatan daya saing industri bandeng Kabupaten Indramayu, mulai dari proses pra produksi, pendederan, pembesaran, pemanenan, hingga transportasi keluar Kabupaten Indramayu. Faktor penentu kedua adalah sumber daya manusia dengan bobot 0,249. Tenaga kerja yang dibutuhkan dalam industri bandeng ini terdiri dari tenaga kerja dengan keahlian terbatas, seperti buruh dan petani, serta tenaga kerja terdidik yang mendukung majunya industri dari segi pengetahuan dan teknologi budidaya. Peran sumber daya manusia sangat strategis terutama untuk lebih memaksimalkan peran kelompok yang berjalan dari tahap pra produksi hingga pemanenan di industri bandeng. Faktor penentu ketiga adalah infrastruktur dengan bobot 0,2. Infrastruktur yang dimaksud adalah infrastruktur dalam kawasan tambak dan transportasi darat serta air. Infrastruktur yang memadai akan menunjang peningkatan industri

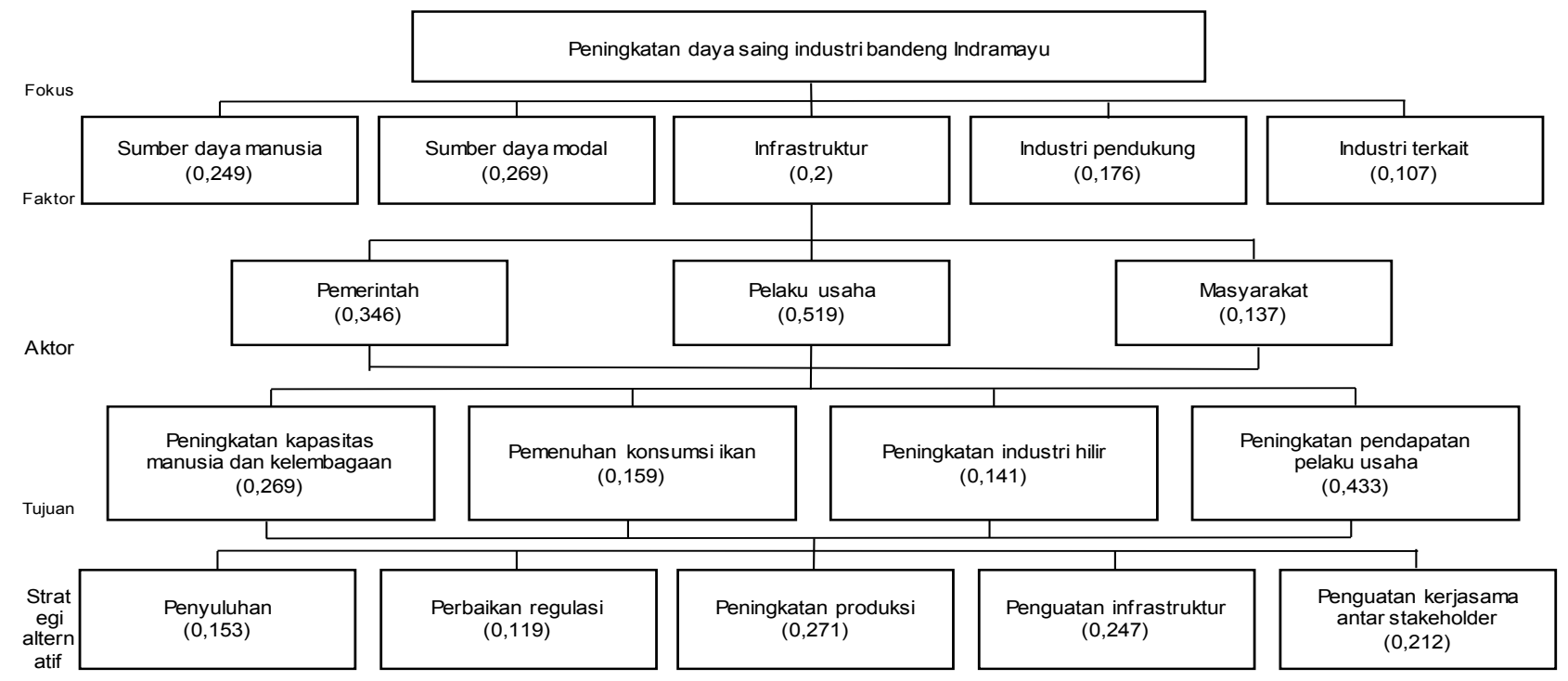

Gambar 2. Hasil Pengolahan Prioritas Peningkatan Daya Saing Industri Bandeng di Kabupaten Indramayu 
bandeng di Kabupaten Indramayu. Faktor penentu keempat adalah industri pendukung dengan bobot 0,176 . Industri pendukung yang dirujuk para pakar dalam penelitian ini adalah industri benih bandeng (nener) dan industri pakan. Saat ini, hampir keseluruhan benih berasal dari Bali. Kualitas benih pun bukan yang terbaik karena benih dengan kualitas terbaik biasanya akan diekspor. Industri pakan sendiri belum begitu diminati para pembudidaya karena budidaya yang masih bersifat tradisional sehingga sebagian besar pembudidaya hanya mengandalkan pakan alami. Padahal sebaiknya pakan buatan pun diberikan pada masa tertentu saat pembesaran bandeng. Faktor penentu yang terakhir adalah industri terkait dengan bobot 0,107 . Industri terkait yang dirujuk para pakar dalam penelitian ini adalah industri alat berat dan perbankan. Industri alat berat berperan sangat penting dalam pembuatan tambak. Industri perbankan berperan dalam penyediaan pinjaman yang akan digunakan sebagai modal maupun biaya operasional.

Aktor prioritas sebagai penentu utama peningkatan daya saing industri bandeng di Kabupaten Indramayu adalah pelaku usaha dengan bobot 0,519 karena saat ini para pelaku usaha menjadi penggerak langsung yang utama dalam industri bandeng dan mendapatkan modal untuk budidaya dari sesama pelaku usaha yang menjadi ketua kelompok pembudidaya atau pengepul. Pelaku usaha dalam lingkup penelitian ini adalah kelompokkelompok pembudidaya yang menjalankan kegiatan budidaya bandeng, mulai dari pra produksi hingga pemanenan. Aktor kedua yang menjadi penentu peningkatan daya saing industri bandeng Kabupaten Indramayu adalah pemerintah dengan bobot 0,346. Pemerintah memiliki beberapa peran penting seperti penyediaan dan perbaikan infrastruktur, memberikan bantuan guna kemudahan akses pada lembaga, serta mengadakan kegiatan-kegiatan yang dapat memberikan nilai tambah pada kegiatan-kegiatan dalam industri bandeng, seperti penyuluhan dan program-program terkait kegiatan budidaya. Aktor terakhir yang menjadi penentu peningkatan daya saing industri bandeng Kabupaten Indramayu adalah masyarakat dengan bobot 0,137. Peran masyarakat hingga saat ini masih kurang dimaksimalkan karena kegiatan dalam industri budidaya bandeng masih cenderung hanya dilakukan di tambak saja. Peran masyarakat dapat ditingkatkan dengan diadakannya kegiatan yang dapat memberikan nilai tambah, seperti pengolahan dan polikultur dengan rumput laut.

Tujuan prioritas dalam peningkatan daya saing industri bandeng adalah peningkatan pendapatan pelaku usaha, dengan bobot 0,433 . Dengan meningkatkan pendapatan pelaku usaha maka diharapkan dapat meningkatkan kesejahteraan para pelaku usaha pula. Peningkatan pendapatan pun akan menunjukkan bahwa industri bandeng mengalami peningkatan produktivitas. Tujuan kedua yang menjadi prioritas penentu utama adalah meningkatkan kapasitas manusia dan kelembagaan dengan bobot 0,269. Peningkatan kapasitas manusia merujuk pada peningkatan kualitas sumber daya manusia dalam industri bandeng. Sumber daya manusia yang berkualitas akan mampu memberikan kinerja yang efektif dan efisien dalam industri. Menurut penelitian Nasution et al. (2012), kelembagaan memiliki peran yang penting dalam konsep kelembagaan karena menjadi sebuah pembawa perubahan (agent of change) dalam komunitas. Keberadaan kelembagaan dapat merangsang pada tingkat pendapatan masyarakat perikanan. Tujuan ketiga yang menjadi prioritas penentu utama adalah pemenuhan konsumsi ikan dengan bobot 0,159. Saat ini, penyerapan bandeng Jawa Barat pun masih berada di peringkat ketiga, maka perlu dilakukan upaya untuk meningkatkan konsumsi ikan. Salah satunya dengan mengadakan Hari Ikan Nasional (Harkanas). Tujuan terakhir yang menjadi prioritas penentu utama adalah peningkatan industri hilir dengan bobot 0,141 . Industri hilir dapat membantu meningkatkan produktivitas industri bandeng Kabupaten Indramayu. Industri hilir yang sudah pernah diterapkan di Kabupaten Indramayu adalah bandeng cabut duri dan pengeringan rumput laut yang dihasilkan dari kegiatan polikultur.

Berdasarkan pendapat para pakar dengan mengacu pada hierarki yang telah ada menunjukkan bahwa strategi yang dapat dilakukan guna meningkatkan daya saing industri bandeng di Kabupaten Indramayu secara berturut-turut adalah melakukan peningkatan produksi $(0,271)$, menguatkan infrastruktur $(0,247)$, menguatkan kerja sama antar stakeholder $(0,212)$, melakukan penyuluhan $(0,153)$, serta melakukan perbaikan regulasi (0,119). Peningkatan produksi dapat dilakukan dengan beberapa cara, seperti, menambah luas lahan tambak, memerhatikan faktor lingkungan, efisiensi dalam hal faktor-faktor produksi, dan melakukan polikultur. Saat ini, kondisi infrastruktur di Kabupaten Indramayu perlu dilakukan beberapa perbaikan dan penguatan, seperti jalan darat dan saluran tambak. Stakeholder dalam industri bandeng adalah para pihak atau aktor yang terkait dalam kegiatan budidaya tambak bandeng di Kabupaten Indramayu yang terdiri dari pemerintah, kelompok pembudidaya, bakul atau pengepul, dan juragan. Kerja sama yang baik antar stakeholder sangat menentukan keberhasilan implementasi kebijakan 
pengembangan industri bandeng Kabupaten Indramayu. Kerja sama dapat dilakukan melalui dua bentuk, yaitu koordinasi internal (koordinasi vertikal dan horizontal) dan koordinasi eksternal (koordinasi horizontal dan diagonal). Penyuluhan maupun pelatihan dapat menjadi sumber pengetahuan terkait pengembangan budidaya tambak dan usahanya. Penyuluhan tersebut dapat diberikan kepada individu, organisasi, maupun sistem. Kegiatan dapat berupa pelatihan serta pengaturan struktur, proses, sumber daya dan model manajemen. Regulasi yang perlu diperbaiki terkait perikanan tambak di Kabupaten Indramayu adalah regulasi yang bersifat merugikan para pelaku usaha, seperti Penerapan Sertifikasi Cara Budidaya Ikan yang Baik (CBIB) yang dianggap mematikan pemasaran ikan pada level usaha kecil. Hal tersebut dapat terjadi karena sertifikasi CBIB tersebut hanya akan mengakomodasi pemasaran ikan pada skala usaha besar. CBIB dinilai tidak memihak pembudidaya lokal berskala usaha kecil karena standardisasi yang belum dapat terpenuhi karena kendala minimnya fasilitas dan infrastruktur.

\section{KESIMPULAN}

Hasil analisis daya saing menggunakan model Porter's diamond dan analisis gap menunjukkan bahwa terdapat beberapa strategi yang dapat dikembangkan guna meningkatkan daya saing industri bandeng di Kabupaten Indramayu, yaitu peningkatan kualitas sumber daya manusia, terciptanya kemudahan akses sumber daya modal, penguatan infrastruktur, serta kemudahan kerja sama dengan industri pendukung dan industri terkait.

Pemerintah sebaiknya menetapkan kebijakan seperti diadakannya kegiatan penyuluhan yang berkelanjutan dan dilakukan evaluasi berkala atas kegiatan tersebut, adanya penjaminan kredit bagi pelaku usaha kecil dan menengah melalui Kredit Usaha Rakyat (KUR) untuk pembinaan kelayakan usaha dalam aspek manajemen sehingga usaha budidaya bandeng yang feasible menjadi bankable, penyediaan tenaga terdidik guna menyediakan program terkait teknologi budidaya dan tenaga kerja di lapangan guna menjalankan kegiatan budidaya, perbaikan sistem saluran tambak yang banyak dikeluhkan karena saluran tambak yang mengalami kerusakan menyebabkan jalan tergenang air dan pembangunan dinding pemecah ombak guna mencegah banjir rob, serta kegiatan yang dapat menunjang kemudahan akses pada industri pendukung dan industri terkait.

Hasil perbandingan berpasangan menggunakan metode AHP menunjukkan bahwa faktor utama yang memengaruhi peningkatan daya saing industri bandeng Kabupaten Indramayu adalah sumber daya modal. Aktor yang memiliki pengaruh paling besar adalah pelakuusaha dengantujuanutama meningkatkan pendapatan pelaku usaha. Strategi alternatif yang menjadi prioritas dalam rangka meningkatkan daya saing industri bandeng di Kabupaten Indramayu adalah strategi peningkatan produksi, penguatan infrastruktur, penguatan kerja sama antar stakeholder, penyuluhan, dan perbaikan regulasi.

\section{DAFTAR PUSTAKA}

\section{Buku}

Listyawan, A.N. (2011). Pengaruh modal usaha. Yogyakarta: Pustaka Pelajar.

Porter, M.E. (1990). The competitive advantage of nations. New York: The Free Press.

Kementerian Kelautan dan Perikanan. (2013). Profil kelautan dan perikanan Provinsi Jawa Barat untuk mendukung industrialisasi KP. Pusat Data Statistik dan Informasi. Sekretariat Jenderal. Kementerian Kelautan dan Perikanan.

Saaty, T.L. (1990). The analytic hierarchy process: planning, priority setting, resource allocating. Pittsburgh: University of Pittsburgh Pers.

\section{Jurnal}

Asaf, R., Athirah, A., \& Ratnawati, E. (2013). Faktor pengelolaan tambak yang mempengaruhi produktvitas tambak di Kabupaten Indramayu Provinsi Jawa Barat. Prosiding Forum Inovasi Teknologi Akuakultur, 1091-1099.

Darmansah, A., Sulistiono, Nugroho, T., \& Supriyono, E. 2016. Pemberdayaan masyarakat melalui pengembangan polikultur bandeng dan udang di Desa Karangsong, Indramayu, Jawa Barat. Agrokreatif. Jurnal IImiah Pengabdian kepada Masyarakat, 2 (2), 92-99.

Demurger, S. (2000). Infrastructure development and economic growth: an explanation for region disparities in China. Journal of Comparative Economics, 29, 95-117.

Fitriantie, M., \& Wahyu, W. 2016. Permodelan konsumsi energi listrik pada sektor industri di Provinsi Jawa Timur menggunakan metode resgresi data panel. Jurnal Sains dan Seni ITS, 5 (2), 169-174.

Kalangi, R. (2015). Pengembangan sumber daya manusia dan kinerja aparat sipil negara di Kabupaten Kepulauan Sangihe Provinsi Sulawesi Utara. Jurnal LPPM Bidang EkoSosBudKum, 2 (1), 1-18. 
Natalia, D. \& Nurozy. (2012). Kinerja daya saing produk perikanan Indonesia di pasar global. Buletin Ilmiah Litbang Perdagangan, 6 (1), 69-88.

\section{Sumber digital}

Azis R. (2017). 10 Strategi Peningkatan Kualitas SDM Pelaku Utama Perikanan. [Internet]. Diperoleh tanggal 4 September 2017, dari http:// dkp.sulselprov.go.id/artikel-29-10-strategipeningkatan-kualitas--sdm-pelaku-utamaperikanan.html

[Bappeda] Badan Perencanaan Pembangunan Daerah Kabupaten Indramayu (2010). Profil Kabupaten Indramayu. Diperoleh tanggal 26 April 2017, dari http://bappedaindramayu.madebychocaholic. com/geografis

[BPS] Badan Pusat Statistik Provinsi Jawa Barat (2017). Angka Partisipasi Murni (APM) Menurut Kabupaten/Kota dan Jenjang Pendidikan Tahun 2011-2015. Diperoleh tanggal 26 April 2017, dari https://jabar.bps.go.id

Dahuri, R. (2010). Tidak Semua Tambak Perlu Direvitalisasi. Diperoleh tanggal 15 Juni 2016, dari http://www.trobos.com/detailberita/2010/03/01/68/2186/prof-dr-irrokhmin-dahuri-ms-tidak-semua-tambak-perludirevitalisasi

DetikFinance.(2015). Tahun ini MenteriSusi Targetkan Produksi 7.2 Miliar Ekor Bibit Bandeng. Diperoleh tanggal 22 Agustus 2017, dari https://finance. detik.com/berita-ekonomi-bisnis/2875373/ tahun-ini-menteri-susi-targetkan-produksi-72miliar-ekor-bibit-bandeng
[DJ PB-KKP] Direktorat Jendral Perikanan Budidaya - Kementerian Kelautan dan Perikanan. (2014). Data Statistik Tahunan Produksi Perikanan Budidaya Indonesia. [Internet]. Diperoleh tanggal 16 Juni 2016, dari http://www.djpb.kkp. go.id/index.php/arsip/c/207/DATA-PRODUKSIPERIKANAN-INDONESIA-DIREKTORATJENDERAL-PERIKANAN-BUDIDAYA/?category_ $\mathrm{id}=35$

Sanjaya. (2016). Ekskavator untuk Perbaikan Saluran Tambak. Diperoleh tanggal 28 Agustus 2017, dari http://www.jabarprov.go.id/index.php/ news/20525/2016/12/20/Ekskavator-UntukPerbaikan-Saluran-Tambak

[SEMILIR] Sistem Informasi Manajemen Lahan dan Air. (2014). Minapolitan Budidaya Kabupaten Indramayu. Diperoleh tanggal 215 Juni 2016, dari http://semilir.kkp.go.id

[SIAK] Sistem Informasi Administrasi Kependudukan tahun 2011. (2017). Penduduk. Diperoleh tanggal 25 April 2017, dari http://jabarprov.go.id

[SIMAqua] Sistem Informasi Manajemen Aquaculture (Perikanan Budidaya). Direktorat Jendral - Perikanan Budidaya. (2015). Kementrian Kelautan dan Perikanan. Diperoleh tanggal 15 Juni 2016, dari http://103.7.52.17/simaqua/

Toiskandar. (2017). Inspirasi bisnis: raup puluhan juta rupiah dari tambak bandeng. Diperoleh tanggal 29 Agusutus 2017, dari http://economy. okezone.com/read/2017/01/28/320/1603658/ inspirasi-bisnis-raup-puluhan-juta-rupiah-daritambak-bandeng 